\title{
Economic History and Development of Port Harcourt, 1912-2003: An Analysis
}

\author{
Grace Malachi Brown, $\mathrm{PhD}$ \\ Lecturer, Department Of History and Diplomatic Studies, Faculty Of Humanities Rivers State University Of \\ Education, P. М. B. 5047, Rumuolumeni, Port Harcourt, Nigeria
}

\begin{abstract}
This study is an analysis of the origin and the establishment of Port Harcourt, how the land was acquired and how a small Port Harcourt settlement developed into a flourishing urban centre. The process by which this transformation took place was analysed, using the theoretical framework of some relevant theories of development and growth models enunciated by different scholars, whose studies were also reviewed. We made a critique of underdevelopment and growth paradigms; and also the problems we encountered in the course of this study. Our findings revealed that companies were either colonially created or that its operations or activities were dependent on the advanced countries with its main links for inputs, markets, management, finance and technology. The study concludes that the positive forces of development were favourable to Port Harcourt and today the city is "the goose that lays the golden egg for Nigeria" and it is popularly known as the "Treasure base of Nigeria", with Nigeria's discovery of oil and gas in 1956.
\end{abstract}

\section{Introduction}

This study examines the establishment, economic development and growth of the Port Harcourt city, from 1912 to 2003. The role of government in economic development of the City, and the assessment of the degree of its economic development vis-a-vis the objective of its creation, will also be analysed.

Additionally, it is hoped that the understanding of the above thematic studies would help to explain the reason behind the domination of the Economic Sector of Port Harcourt by non-indigenes. It was the ease with which the non-indigenous inhabitants acquired land and dominated the various economic activities in the City that made them to assert that Port Harcourt was a "no man's land".

As this study is an exposition of economic development of Port Harcourt from its creation in 19122003, it will add to knowledge about Nigerian communities generally and Port Harcourt in particular. Also, the enlightenment of this study is likely to attract the attention of further studies by scholars and academicians in the field of economic history of Port Harcourt.

We have chosen the period 1912 - 2003 because Port Harcourt was created in 1912 and 2003 marked the end of the civilian administration of Chief Olusegun Obasanjo's first tenure in office as the President and Commander-in-Chief of the Armed Forces of the Federal Republic of Nigeria.

\section{Statement Of The Problem}

Scholars have not paid attention to Economic History of Port Harcourt, despite the fact that this city was a deliberate creation of colonial government as a Sea Port terminal. The first work on Economic History of Port Harcourt was the researcher's Master degree thesis titled: "An Economic History of Port Harcourt 1912$1975^{\prime \prime}$.

It is appalling to note that this aspect of history has been neglected. Most research work on Port Harcourt was written by geographers, economists, sociologists and political scientists. None has documented in any depth the economic history of Port Harcourt. This is in contrast to (Harald, Hagemann and George Erber, p.12) vie w, that economic factor is a major factor worth consideration in any historical interpretation. Also (U. O. A. Esse p. 3) emphasized that economic factors and offered explanations for most of the decisions and actions of rulers.

The challenge of this study will unravel the follo wing problems:

(a) To ascertain the rate of economic develop ment and growth of Port Harcourt between 1912 and 2003; As our study itself is an analysis of the economic history of Port Harcourt, it is our hope that it will add to the existing historical knowledge of Nigerian communities and cities;

(b) The rate and pattern of the economic development of the City we have analyzed, should guide scholars in their assessment of the impact of colonia lis $m$ and the operations of mult inational corporations 


\section{Sources And Methodology}

In the practice of history, the historian uses so many sources in the reconstruction of his work. In this research, we have considered it necessary to use the following sources and methods: Oral History, archival materials and interdisciplinary approach. Oral tradition, according to Jan Vansina, is a testimony transmitted verbally from one generation to another (Vansina in Kizeribo ed p. 42). He was of the opinion that African historians must make use of oral traditional sources if they are to present objective history of any African Society. Supporting this view. E. J. Alagoa observed that most African communities have the greatest part of their past recorded in Oral trad ition (Kiabara p.12).

In corroborating this view, S.P.M. Ekanza in his Oral Tradition and the Writing of History (p.82), opined that any African history which under-estimates oral tradition or relies exclusively on written documents cannot be regarded as authentic history. In keeping with these views, Alagoa (p.9) defined oral tradition as a historical information transmitted orally by a process peculiar to each community and which should be studied first in the context or its culture before being made available for cross-cultural analysis and comparison.

We have also relied on eye witness accounts; these are evidences collected from actors, participants and all those who in one way or the other participated in economic transformation of Port Harcourt. Oral interviews were conducted and informants were randomly selected from different Diobu and Okrika communities, groups, individuals, company directors, government officials, traders, farmers, fishermen and transporters. This was done in order to obtain variant information bearing in mind the problems associated with oral tradition and eye witness account. Uya (p.17) observed that, in eye witness account the interviewee will be talking from his or her own vantage point and will be highly personalized and subjective.

The collection of oral evidences is not very easy. Therefore, to keep a proper record of the traditions collected, we made field-note and carefully recorded the dates and places of interview, names, ages and status of our informants. And we also used the recorder to record some of the information in course of our field work. Again, we considered the fact that oral evidence can sometimes be distorted or falsified due to failure in human memory. We have approached the oral data with a critical frame of mind in order to arrive at objective interpretation. However, as Port Harcourt is today a cosmopolitan city, its economic history cannot be written by collecting data from indigenes alone. Accordingly, we interviewed people from different parts of Nigeria who are at present living and working in the city to obtain data on the contemporary situation.

Other sources used are written materials and Intelligence Reports on Port Harcourt. As ind icated earlier in the literature review, there is a dearth of material on the area of our study. Therefore, to complement the oral data we visited both libraries and archives to obtain written information on Port Harcourt. Related literatures on agriculture, economics, geography, sociology and politics were also explored. The use of these related literatures is to give room for inter-disciplinary approach since the historian cannot alone answer all the questions that he must ask in the pursuit of his vocation (Alagoa p.13).

In the course of our research we encountered some difficulties. First, was insufficient materials on the areas of study.

Secondly, there was lack of co-operation on the part of the people to be interviewed especially the Oil Industries due to their tight security network. Some informants who tried to grant audience hid some information either for political reasons or fear of litigation. When sensitive questions were asked, they simply responded thus "I reserve my comments".

There was also problem of transportation as we had to travel from one village in Port Harcourt to another and to different business locations. Most times the informants were busy, we had to reschedule the time at their convenient. Oftentimes interview locations were changed to suit the interviewee. In spite of these problems, we persevered and successfully completed our study.

\section{Theoretical Frame work}

As the focus of this study is based on economic development and growth, we shall therefore examine some relevant theories of development and growth as enunciated by different scholars.

According to Harald, economic growth is the increase in value of the goods and services produced by an economy. It is generally a factor in an increase in the income of a nation. It is conventionally measured as the percent rate of increase in real gross domestic product (GDP); while economic growth theory refers to growth of potential output. He further observed that this production is at "full employment" when it is caused by growth in aggregate demand or observed output (Harald p.262).

The major proponent of economic growth theory was the neo-classical growth model. It was developed by Robert Solow in the 1950s. The model believes that a sustained increase in capital investment increases the growth rate temporarily. This is because the ratio of capital to labour goes up (there is more capital available for each worker to use) but the marg inal product of additional units of capital is an assessment to 
decline and the economy eventually moves back to a long-term growth, with real Gross Domestic Product (GDP) growing at the same rate as the workforce plus a factor to reflect improving productivity.

In essence, the neo-classical growth model has argued that increasing capital relative to labour creates economic growth since people can be more productive given more capital. Secondly, poor countries with less capital per person will grow faster because each investment in capital will produce a higher return than rich countries with ample capital. Thirdly, because of diminishing returns to capital, economies will eventually reach a point at which there is no new increase in capital will create economic growth. This point is called a "steady state" (Harald P. 263). The model also notes that countries can overcome this steady state and continue growing by inventing new technology that allows production with fewer resources; but the model assumes technological progress, "eoxygenizing" technology from the model.

Unsatisfied with the Solow's explanation, economists worked to "endogenize" technology in the 1980s. They developed the endogenous growth theory that includes a mathematical explanation of technological advancement. This model also incorporated a new concept of human capital, the skills and knowledge that make workers productive. Unlike physical capital, human capital has increasing rates of return. Therefore, overall there are constant returns to capital and economies never reached a steady state. Growth does not slow as capital accumulates, but the rate of growth depends on the types of capital a country invests in.

The Harord-Domar growth model delineates a functional economic relationship in which the growth rate of gross domestic product depends directly on the national saving ratio and inversely on the national capital/output ratio. This synthesis of analyses of growth model was proposed by Sir Roy Harord of Britain and Evsey Domar of USA, hence it was named Harord-Domar models after their names. The model was commonly used by developing countries in economic planning in the early post world wars years (Geng and Harald p.5).

If the country is not capable of generating a desired level of saving, it becomes a justification or an excuse for borrowing from international agencies.

Economic development as a concept could be said to be vague, complex and multi dimensional. It means many things to different people. In other words, economic development does not have a straight -jacket definition. In a broader sense, it could mean the development of the economic wealth of countries or regions for the well-being of their inhabitants. Still, econo mic development could also mean a sustainable increase in living standards that implies an increased per capita income, better education and health as well as environmental protection.

To the Liberal school of thought, development was inextricably tied to the economic perspective. Most Liberal theorists see it as economic development which could be gauged in terms of the growth of the Gross National Products (GNP). According to Michael Todaro, a Liberal theorist, economic developments must aimed at achieving these three necessary goals (Michael Todaro P. 140):

(1) producing more life sustaining necessities such as food, shelter and health care and broadening their distribution;

(2) raising standards of living and individual self-esteem; and

(3) expanding economic and social choice and reducing fear.

By this definition, Todaro re-echoed Dudley Seers that economic development should be able to reduce or eliminate poverty, inequality and unemployment within the context of a growing economy (Dudley Seers P.3). These Liberal scholars were of the view that development encompasses more than the financial and material side of people's lives.

The Marxist scholars sees development in a different perspective while the Liberal scholars looked at development purely on economic point of view and that is the material aspect, which means the dialectical materialis $\mathrm{m}$. The Marxist view development at three broad levels - the individual level, social group level and mode of production (Okereke and Ekpe P.5). At the individual level, human beings are seen as the epicenter of development. This means that an individual had to develop his mental capability, academic, moral and material well-being; for instance the development of man will lead to increase in productivity, ability to harness the forces of nature and the capacity for man to make a living in the face of harsh natural forces. From the Marxist view point this process of development does not influence much by increase in capital or the rise in Gross National Product (GNP). The radical scholars maintained that the first step towards development is the overall improvement of man who is expected to be vanguard of transformation and change. In view of how man can be developed in order to serve as the precursor of society's development, some Marxist scholars advocated thus:

(1) Free, compulsory and universal education;

(2) Improvement of the general educational, cultural and technical training of the working population;

(3) Raising of people's living standards to a qualitative and new height; 
(4) Improvement of people's health and extending their active life through a system of Universal health checks in the polyclinics, hospitals and sanatoriums; and

(5) Ensuring that the levels and structures of consumption of material, social and spiritual services are raised (Okereke and Ekpe p.6).

Other Marxist scholars such as Rodney, Lenin, Franc and Nkurumah had earlier postulated this view. For example, Walter Rodney described development when he stated thus:

"Development in human society is a many-sided process. At the levels of individual, it implies increased skill and capacity, greater freedom, creativity, self discipline, responsibility and material well being. At the level of social groups, it implies an increasing capacity to regulate both internal and external relations... In the past development has always meant the increase in the ability to guard the independence of the social group" (Rodney p.11).

The radical scholars attacked capitalis $\mathrm{m}$ and imperialis $\mathrm{m}$ as not being able to generate development. Nkrumah argued that foreign capital is used for exploitation rather than development of less developed parts of the world (Nkru mah p. 30).

To the Marxist, irrespective of the angle one looks at development, it is indeed synonymous with socialist mode of production. All other modes of production that preceded it are seen to have been transient. That is to say, they were temporary and had to pave way to socialis $\mathrm{m}$.

From our analyses of both the liberal and Marxist perceptions, development is a multidimensional process involving changes in structures, attitudes and institutions as well as the accele ration of economic growth and eradication of poverty. This study encompasses both the Marxist and liberal concept of development and this take into account not only economic factors, but also human development as well. From this standpoint, development in this work implies the transformation of the society and also changes in material and financial lives of people.

According to Pattel and Leibenstein, western economics on the Third World societies has placed high premium on the characterizations of the developed and the underdeveloped countries. More often than not, the question is phrased as how to change from one type of society to another. The society whose state of being has to be changed is the underdeveloped country. The society which is the model for this change, is the developed country, symbolized by the West. As found in the tradition of mainstream Western political scientist and sociologists, economists have also attempted to make the distinction between the developed and the underdeveloped countries particularly, in reference to the national income per capital and a set of features which include social and political variables (Pattel p.34 and Leibenstein p.45). In the work of Sauvy, the characteristics of underdevelopment are:-

i short life expectancy;

ii High birth rate

iii malnutrition

iv meager capital supply and unemployment;

v illiteracy;

vi low status of women;

vii dominance of the agriculture sector;

viii rudimentary middle class; and

ix political authoritarian ism (Sauvy p. 18).

According to Ake, Leibenstein lists are even more comprehensive. The first, he call incomedetermining and the other, he calls income-determined characteristics. Lack of Leibenstein incomedetermining, the following apply: lack of entrepreneurship, technical knowledge, credit systems, savings employ ment opportunities, and low volume of trade per capita (Ake P.27).

The income-determining characteristics include poor housing, major proportion of expenditures on food and basic necessities, malnutrition, high indebtedness relative to assets and income, rudimentary hygiene and sanitation. The developed countries are the ones that have the opposites. Rostow provides five stages of development as typified by the Western model:

i) traditional society;

ii) the traditional stage;

iii) the take-off stage (the crucial stages of investment increases to revolutionize technique of production relative to per capital output);

iv) the drive to maturity; and

v) the stage of high mas s consumption (Rostow P. 36) 
Ake argues that although many Third World leaders and scholars appear to accept willingly or even actively to pursue the capitalist path to development it should not be taken as a sufficient proof that Western scholarship is not imperialism (A ke P.29).

The other point of contention by Ake is the tendency on the part of Western scholarship to deepen on inferiority complex among Third World peoples and thus render them more psychologically and economically dependent on external stimuli of the Western countries.

Instead of Third World societies looking in wards, trusting in their respective domestic strength and realities for development in itiatives, they tend more to allow development theories of Western social science to guide their knowledge of develop ment variables.

The term "dependence" could be viewed from economic or technological perspective and it is often used to describe a relationship between countries and one which, like the relationship between persons from which it is derived, is not susceptible to rigorous definition. The nature of the concept is that it is imprecise, describing a syndrome of symptoms; this does not mean that the concept is useless - but it does mean that a search for a watertight definition is misplaced.

Technological dependence arises where the major source of a country's technology come from abroad. In the case of third world countries, the major source is advanced countries. The dependence is greater, the greater the extent of reliance on foreign technology, and the more concentrated the source. That is to say, a country should be described as more technologically dependent if all its foreign technology comes from a single country, than if its sources are spread among a number of countries. In some cases sources are widely and evenly spread over the economy as a whole, but in each individual industry, the source is concentrated. This too is an aspect of technological dependence.

All societies from substance to the most advanced operate a technology, be it implicit or explicit. In some societies there are more formal means for transmitting this knowledge than in others. In some it is largely a question of word of mouth and imitation; in other complex systems of education have developed, and technology has been commercialized. Commercialization of technology occurs when it becomes part of a system of property, and its transfer is no longer free; the knowledge is monopolized and bought and sold. The commercialization of technology developed along with the rapid increase in technological change, during the industrialization that occurred in the nineteenth and twentieth centuries.

In most societies, a whole variety of means of acquiring and trans mitting knowledge coexist. Informal and traditional means of transferring technology continue for some areas of life, and in some sectors of the economy, while in the modern parts of the economy, commercialization of technology has taken root. This coexistence of different types of transmission is true even in the most advanced economies, where commercialization has penetrated most widely and deeply. In developing countries, where in many cases the modern sector covers only a minority of total activity, informal systems of transmission form a correspondingly large part of total technology transmission. Technological dependence describes this situation of almost exclusive reliance on advanced-country technology, with a little adaptation in the formal sector. The informal sector covers activities in the rest of the economy which have not been absorbed wholly into the formal sector, or, put in another way, into the advanced countries industrial system.

According to Stewart, the dependency theorists (Furtado, Frank, Sunkel, Dos Santos, Szentes, Amin and Griffin, etc) are concerned with the whole relationship between advanced countries and third world countries: the dependent relationship is exhibited in cultural as well as economic features of third world countries (Stewart p. 114-115).

The transfer of technology from advanced countries has enabled countries of the third world to benefit from the manifold developments of science and technology in the industrialized countries, during the past two hundred years. The transfer has permitted countries to use this technology without themselves going through the difficult and costly process of developing it. This is one of the main advantages of being a late-comer in terms of development. Much has been written about the advantages thus conferred on third world countries, in discussion of foreign investment and of technology transfer. Not only has technology transfer permitted the use of high-productivity techniques; it has also, in many cases, inspired the desire for technical changes, which forms an essential basis of industrial development, whether based on imported or locally developed technology.

However, the late-co mer advantages of technology transfer form a backg round to the discussion. While the advantages are often not overriding, they may explain why a country may be justified in pursuing a policy of technology transfer, and hence permitting the associated technological dependence, despite the considerable costs so incurred.

Spencer, Merhow, Stewart and Akpuru-Aja have argued that the two advantages of technology transfer mentioned arise from transfer of technology, not from dependence, whilst the undesirable consequences arise from technological dependence, rather than transfer as such. That is to say the main disadvantages of technology to the third world arise from the fact that they are technologically dependent on the advanced 
countries, and receive their technology in a more or less one-way flow from them, not from exchange in technology as such, which may confer considerable advantages (Spencer p.43, Merhow p.45, Stewart p. 122 and Akpuru-Aja p. 64).

Also, Stewart stated that the undesirable consequences of technological dependence may usefully be classified into four categories:

i) $\cos \mathrm{t}$

ii) loss of control over decisions;

iii) unsuitable characteristics of the technology received;

iv) lack of effective indigenous, scientific and innovative capacity, which is itself a symptom of underdevelopment (Stewart p. 123).

The four categories are interrelated, affecting and reinforcing each other. Each has consequences for the extent and pattern of development.

Joshi have argued that the economic system itself generate itself the factor prices and factor reward which form the incentive for further economic activity and help determine technological choice (Joshi P.35). While other scholars (Hirsch, Griffin, Freeman, Helleiner, Sharpston, Burenstam Liner and Vernon) have argued in direct contrast to the neo-classical theory, that trade flows are likely to be greatest between countries at a similar stage of development. This arises from the close relationship between income le vel, consumption and production patterns. They further argued that the following two theories arise from growth within the economic system:-

(a) One relates to the rate of growth to the absolute size of the initial base: this could be explained by economies of scale in growth-producing activities, e.g. Research and Development, or by the fact that the size of growth-re lated activities is positively related to the size of the output (e.g. savings proportion and $\mathrm{R}$ and $\mathrm{D}$ as a proportion of total inco me);

(b) The other theory relates the rate of growth to the past rate of growth. This could result from a particular type of technical progress, positively related to the rate of growth of output and capital stock.

Stewart has argued that growth may be limited by:-

(a) limitations on investment set by absorptive capacity;

(b) limitations on investment set by willingness to invest;

(c) limitations on savings and therefore investment set by difficulties in restraining lu xury consumption;

(d) limitations on savings set by necessary consumption;

(e) limitations on investment set by the sum of local I goods capacity and foreign exchange availability (Stewart P.150).

\section{A Critique Of Underdelopment, Economic Development And Growth Paradigms}

Okereke and Ekpe have argued that regardless of the seemingly sound and logical methodological tradition of the underdevelopment that has arisen from economic development and growth theories and notwithstanding the growing theoretical complexity and sophistication of some of the models within it, this paradigm has not escaped the critical lenses of scholars (Okereke and Ekpe P.74). Palma has observed its sudden ascendancy as the dominant paradigm in the analysis of development, growth and underdevelopment has been accompanied by theoretical controversies aimed at either supporting or refuting its major thesis (Palma P.881-882).

The first set of critics are those that Andre Gunder Frank refers to as the critics of the right. These critics are principally concerned with only an aspect of the underdevelopment theory, that is the dependency theory. These critics include scholars like Lall, Meier, Cardoso, Roxborough and Zartman, just to mention but few of them.

Lall has challenged the methodological and conceptual correctness of the propositions underlying a number of dependency studies. He argues that the characteristics to which underdevelopment in dependent countries are generally attributed not exclusive to those economies, but are also found in so-called non-dependent economies as well. He adds that they are, properly speaking, characteristic of capitalist development in general and not necessarily only of dependent capitalis $\mathrm{m}$. He further argues that such analyses are faulty and misleading given the fact that they cannot show causal relationship between these characteristics and underdevelopment. Lall brilliantly argues that for any concept of dependency to lay claim of being a theory of underdevelopment, it must satisfy two criteria, namely; 
(1) It must lay down certain characteristics of dependent economies which are not found in non-dependent ones. These characteristics must be shown to affect adversely the course and pattern of development of dependent countries.

(2) That if crucial features of dependence can also exist in both dependent and non-dependent economies, then the whole conceptual scheme upon which dependency theory is based is effective. He concludes that the technique used by the dependency theorists is to pick off some salient feature and put them into a distinct category of dependence (Lall p. 799-882).

Dependency theory is static not in the sense that it precludes possibilities of dynamic development, but in the sense that it takes dependency, however defined as given, only its form changing; it conjures away the possibility that dependency may be a declining phenomenon.

Perhaps the most incisive criticism of the dependency theory is that of Ernesto Laclau. Writing from a radically different perspective, Laclau attacks Frank work in all flanks. For instance, he argues that Frank definition of capitalism lacks orthodox Marxist flavor as it emphasizes exchange and commercial relationships rather than the process of production. Furthermore, he argues that Frank confuses participation in the world capitalist economic system with the dominance of the capitalist mode of production in Latin America. He also dismisses Frank claim that Latin America has been a capitalist society since the beginning of the $16^{\text {th }}$ century as false.

It is the writer's contention that most of the criticisms leveled against dependency, underdevelopment, economic development and growth, arose from unverifiable perception or comprehension of the subject matter. For instance, the model of evaluation or assessment used in one society may not be workable or applicable in another, having regard the peculiar circumstances of that given society. Okereke and Ekpe have also argued that this paradigm provides multi-dimensional angles which from which to grapple with these theories of economic development and growth (Okereke and Ekpe P.79).

\section{Application Of These Theories To Our Study}

An investigation of our study revealed that the economic development of Port Harcourt from 1912 to 2003, were as a result of the fact that the companies were either colonially created or that its operations or activities were dependent on the advanced countries and with its main links for inputs, markets, managements, finance and technology.

The dependent relationship means that the advanced countries' interests are internalized, inhibiting independent action to counter technological dependence. The situation is self-reinforcing because once advanced, it creates a society in its own image, requiring further import of technology to feed the markets which have been created, and to enable the industries to survive and expand. Given a productive structure based on the production of advanced countries products, using advanced-country techniques, the natural consequence is that the local science and technological systems are small and irrelevant, adept at assimilating undated foreign technology, but lacking independent innovatory force. Yet the weakness base is not only an outcome but also a prime cause of technological dependence. Attempts to break out of the vicious circle that has been created tend to be thwarted by the attitudes and interests developed as a result of the dependent relationship and which may likely affect or influence the economic, social and political structures that have been created from this dependence. The writing of Fernando Henrique Cardoso supports this view, when he asserts that capitalists development, take place with dependent situations which bring imperialis $m$ and thereby give rise to underdevelopment (Fernando Henrique Cardoso p. 83-95). Many of the mu ltinational corporations like United Africa Company (UAC), Patterson Zochonis (PZ), Lever Brothers, Coca-Cola, Shell, Mobil, Elf, Agip, etc are powerful conglomerates whose resources base are so formidable to the point of weakening any challenge and competition from indigenous entrepreneurs.

According to Okereke and Ekpe, these multinational companies "straddle their host economies like colossus and their domination is hardly challenged" (Okereke and Ekpe p.113). This may be why Nkrumah sees the multinational corporations as epitomes of neo-colonialis $\mathrm{m}$ and hence agents of imperialism (Nkru mah p.13). As Chinweizu summarized, the neo-colonial domination of the economics of third world countries marked the beginning of the process of ensuring the "chronic underdevelopment and slow impoverishment" of these societies. Thus, having been "progressively impoverished" by the combination of economic weakness, adverse terms and structures of world trade, foreign investment, inability to nationalise or even supervise foreign enterprises, the weak economy develops more and more weakness, and plunges deeper and deeper into acute debt (Chinwerizu p.463). However, this study took into account the views of the various schools of thought (be it the Marxian, liberal, neoclassical and dependency), and came to the conclusion that the presence of these companies within Port Harcourt municipality, has assisted to develop the city economically by creating employment, welfare and social services within the context of third world coun tries. 


\section{Lite rature Review}

Although in the National and State archives, there exist Colonial reports and documents about Port Harcourt, there is still a dearth of literature on the city.

There seems to be no published work on Port Harcourt before the 1970s. Ogionwo (p.3) recognized this fact when he observed:

...Until very recently, the Rivers State had been a neglected area in terms of research; no Nigerian Government or University had attempted to emphasize research into that state in spite of its rich cultural and historical heritage and its present position as the centre of the country's booming oil industry...

Taking the lead in research into Port Harcourt, W. Ogionwo in his two works, The City of Port Harcourt: A symposium on its Growth and Development (Ibadan, 1979) and A Social Survey of Port Harcourt (Ibadan, 1979) focused on the historical and social development of the city. However, in his volumes he made a skeletal exposition of the business potentials in Port Harcourt's industrial and commercial sectors. In his discussion, he limited himself to investments or businesses of the micro order, such as road construction, education industry, food processing industry and medical laboratory. He also examined crops, animal resources and the marketing of agricultural products and concluded that even though the city's agricultural resources now seem not to be great, the potentials were great. Using Ogionwo's works as a foundation, detailed research would be made on the economic history and development of Port Harcourt.

In the same way, C. N. Anyanwu in his Ph.D Thesis, Port Harcourt 1912-1975: A Study in the Rise and Development of a Nigerian Municipality (Ibadan, 1971) discussed the founding of Port Harcourt and its emergent urbanization. Although he provided rich insight into the city's settlement pattern and its oil boom, other aspects of the economy such as trade, agriculture, banking and transport and communications were not discussed.

H. E. Wolpe in his Ph.D Thesis titled, Port Harcourt, A Community of Strangers: The Politics of Urban Development in Eastern Nigeria (M.I.T., 1966) saw Port Harcourt as a city co mpletely occupied by a population from various African countries. Statistically, he showed that the Igbo, Ibibio, Yoruba, Edo, Hausa, Nupe, Tiv and other non Nigerian populations in Port Harcourt were about $88 \%$ while the remaining percentage was made up of people from the immediate and surrounding communities. His study seems to suggest that Port Harcourt has been a "no man's land" since its establishment. The city, as our research would show, has original inhabitants who prior to the establishment of the city had used the land and its adjoining creeks for farming and fishing.

E. I. En iatorudabo in her Inter-Group Relations and Development in Port Harcourt City Local Government Area: A Historical Perspective. M. A. Thesis (Uniport, 1992) described the evolution of Port Harcourt and the severed social relationship between the Okrika and Ikwerre ethnic groups. These unhealthy relations, she said, arose out of claim and counter claim by both groups over the ownership of Port Harcourt. In her study she opined that out of the initial 25 square miles of land acquired by the Colonial Govern ment, Okrika owned 15 square miles, Diobu had 6 square miles while other villages around Diobu owned 4 square miles. Her work rather than suggesting some possible ways of reducing the already severed relationship aggravated it, as she apportioned more than half of the total land to the Okrika without a detailed proof of how they came to own such. She did not analyse how the Okrika village in Port Harcourt migrated across the Bonny River to settle in their present place. The people she referred to as "other villages around Diobu" were not people from another ethnic group but were other Diobu villages.

Though R. O. Ekundare's work, An Economic History of Nigeria 1860-1960 (London, 1973) never had Port Harcourt as its main thrust, it identified some of the economic potentials of Port Harcourt such as harbour facilities, industries, port, railway and roads. Ekundare did not say how these economic potentials influence the life of the inhabitants of Port Harcourt.

Again, G. B. Stapleton in his The Wealth of Nigeria (London, 1967), mentioned railways, port, commerce and industry as the main economic resources of Port Harcourt. His work, which generally stressed the problems of Nigerian economic development, did not make any detailed analysis of the resources of Port Harcourt.

Two works on the development of petroleum in Nigeria, L. H. Schatzl, Petroleum in Nigeria (New York, 1969), and S. R. Pearson, Petroleum and the Nigeria Economy (California, 1970), traced the historical development of petroleu $m$ in Nigeria. In their works they showed that the search for crude oil in the country was initiated in 1937 by Shell B. P. Petroleum Development Company and that the first commercial production of crude oil was in Oloibiri in 1957 and then, Port Harcourt in 1958. Both scholars, however, did not pay attention to the effects on Nigeria in general and Port Harcourt in particular.

W. I. Ofonagoro in his work, Trade and Imperialis m in Southern Nigeria 1881-1929 (Lagos, 1979), noted that Port Harcourt played a vital role in the promotion of export and import trades in Nigeria through the existence of its natural harbour and construction of railway across the city by the Colonial Govern ment. 
B. Odogu's work, Multi-national Corporations and Development: The Case of John Holt of Nigeria Plc (M. A. History, Thesis, Uniport, 1998), devoted attention to the analysis of the history of John Holt in Nigeria. Although he pointed out that John Holt established its branch office in Port Harcourt, he did not identify the other trading companies that had Port Harcourt as their strong-hold.

V. U. Ehimiye's BSc research project titled: Spatial Variation in Housing Rent in Port Harcourt: A Case Study of Diobu Miles 1, 2, 3 and main town (1987), highlighted the housing problems in Port Harcourt. She compared the variations of rent payment in different parts of Port Harcourt and came to the conclusion that the rent payment is not commensurable to the facilities in the house. Ehimiye did not link the housing problems in Port Harcourt to the economic growth of the city which prompted the high population density.

L. O. Akpomiemie's BSc project work on Location and Work Place Relations: A Case Study of Elf Nigeria Limited, Trans-Amadi Industrial Layout, Port Harcourt emphasized employer and employee relationship. She also examined the effects of employ ment of immigrants to the sector so as to compare with Elf Nigeria Limited: however one cannot ascertain the rate of economic growth in a society based on one sector of the economy.

N. D. Beredugo wrote on Urbanization and Crime: A Case Study of Port Harcourt (1985). It was a project for the award of Bachelor of Science degree in Sociology. He focused on the characteristics of urbanization which he listed as population density, close proximity to the sea, river and natural resources and institutions. Beredugo also described what crime is and punishment proffered to violators. He failed to examine what gave rise to urbanizarion and how economic growth led to urbanization.

The work of W. E. Spiff on the Hotel Industry in Port Harcourt (BSc Geography project 1986), was a catalogue of some of the Hotels in Port Harcourt. He was interested in vocational patterns of the Hotels and also classified the users according to their income. The work was more of a tourist guide to visitors coming into Port Harcourt. The writer did not link the establishment of hotels to economic development and also state how these hotels contributed to economic growth of the city.

R. K. Udo and A. B. Mamman (eds) work on Nigeria: Giant in the tropics, volume II State Survey was an analysis of the various movement towards the creation of the Rivers State in 1967. Port Harcourt was mentioned as one of the most dominant economic nodes of Nigeria with reference to the oil industry. The book is like a city guide to tourists into Rivers State. The authors did not say in detail how the various economic activities contributed to the growth of Port Harcourt City.

C. U. Oyegun and O. A. Adeyo's (eds) work on Port Harcourt Region 1999 was a geographical survey of the entire Rivers State. Though some aspect of economic activities in Port Harcourt were mentioned in passing, the authors were more concerned with economic concepts, definitions, geology and physical environment of the region. They did not place much emphasis on the economic development of Port Harcourt City in particular. However, the book assisted us greatly in this study.

Our analysis of the existing literatures shows that none of the works had taking an in-depth study of the economic history of Port Harcourt.

\section{Conclusion}

The study has thrown light that the economic history and development of Port Harcourt was facilitated by the British colonial masters, as they established companies and businesses in the city mainly for economic purposes, by creating employ ment, welfare and social services within the context of third world countries. The city is presently the mainstay of the Nigerian economy (be it oil and gas, energy and all forms of economic and technological development of the Nigerian state).

The study has further thrown light that in spite of the important role of the city to the Nigerian state, there are dearth of literature on Port Harcourt, and apart from this author, most of the early researchers were not historians and had undertaken their respective research on the city from their own fields of specialization without an in-dept study of the city from purely historical standpoint such as economy, trade, agriculture, banking and transport, property development, communications and so on; and how these activities influenced the life of the inhabitants of Port Harcourt.

\section{References}

[1]. Alagoa Ebiegberi J., "Oral Tradition and Archaeology: The case of Oyoma”, Oduma, Vol.1, No. 1, Port Harcourt: Rivers State Arts and Cult ure, (1973): 13.

[2]. Alagoa Ebiegberi J. and Tekena Tamuno N., (eds.), Land and People of Nigeria: Rivers State. Port Harcourt: Riverside Communications, 1989.

[3]. Alagoa, Ebiegberi J. "Oral Traditions and History in Africa”, Kiabara, Vol. 1., Port Harcourt: School of Humanities, University of Port Harcourt, (1978): 4-10.

[4]. Alagoa, Ebiegberi, J. (ed.), Oral Tradition and Oral History in Africa and Diaspora: Theory and Practice. Lagos Centre for Blacks and African Arts and Civilization, 1990.

[5]. Alagoa Ebiegberi J. "The Relationship Between History and other Disciplines", Tarikh, Vol. 6, 1, Historical Society of Nigeria, (1978): 12. 
[6]. Ake, Claude, A Political Economy of Africa, England: Longman Group Limited, 1981.

[7]. Akpuru-Aja, Aja, Fundamentals of Modern Political Economy and International Economic Relations: Changing with the Times, Owerri: Data-Globe Nigeria, 1998.

[8]. Chinweizu, The West and the Rest of Us, London: Nok Publishers, 1978.

[9]. Dudley, Seers, "The Meaning of Development", Eleventh World Conference of the Society for International Development, New Delhi, 1987.

[10]. Fernando, Henrique Cardoso, "Dependency and Development in Lat in America", New Left Review, vol. 74 July-August, 1972.

[11]. Harald, Hagemann and George Erber, "Growth, Structural Change, and Employment", Frontiers of Economics, ed Klaus Zimmermann F New York: Springer-Verlag, 2002: 269-310.

[12]. Lall, Stephen, "Is Dependency a Useful Concept in Analyzing Underdevelopment”, World Development, Vol. 2 No. 11,1975:10-12.

[13]. Merhar, Michael, Technological Dependence, Monopoly and Growth, London: Pergamon Press, 1968.

[14]. Ofonagoro Ibekwe, W. The Commercial Decline of the Eastern Delta. London: Nok Publishers International. 1979,

[15]. Ofonagoro Ibekwe, W. Trade and Imperialism in Southem Nigeria London: Nok Publishers International, 1969.

[16]. Ogionwo, W.(eds.) The City of Port Harcourt: A Sympsium on its Growth and Development. Ibadan: Heinemann Educational Books Limited. 1979,

[17]. Ogionwo, W. A (eds.) Social Survey of Port Harcourt. Ibadan: Heinemann Educational Books Limited, 1979,

[18]. Palma, Geoffrey, "Dependency: A Formal Theory of Underdevelopment or a Methodology for the Analysis of Concrete Situations of Underdevelopment", World Development Vol. 6 No. 7, 1983:15.

[19]. Patel, Stephen, I., "The Economic Distance Between Nations, its Origins Measurement and Outlook", The Economic Plural No. 293 London, 1964.

[20]. Spencer, David L., Technology Gap in Perspective, Cornell University Press, 1970.

[21]. Stewart, Frances, Technology and Underdevelopment, London: The Macmillan Press Ltd, 1977.

[22]. Todaro, Michael P. Economics for a developing World, Longman Group Limited Enugu 1979. Uya, Okon, E., "Oral History: Some Problems in Methodology andPerspectives" The Significance of Historical Research. Ed Willia ms.L. A. Department of History, Howard University, 1973:17.

[23]. Uya, Okon, E., "Trends and Perspectives in Africa History" Perspective and Methods of Studying African History. Eds. Erim O. Erim and Uya, Okon E., Enugu: Fourth Dimension Publishing Company Limited, 1984.

[24]. Vansina Jan, Oral Tradition as History, London: James Curry Limited, 1985.

[25]. Walter, Rodney, How Europe Underdeveloped Africa, London: Bogle- C'ouverture Publications, 1972. 